Arch. Tierz., Dummerstorf 45 (2002) 1, 79-85

Institute of Genetics and Animal Breeding, Jastrzębiec, 05-551 Mroków, Poland ADAM KOŁĄTAJ, JÓZEF KLEWIEC, ANNA MARIA KONECKA, ARTUR JÓŹWIK
and ANNA ŚLIWA-JÓŻK

\title{
Influence of protein starvation on some lysosomal enzyme activities in blood serum of sheep
}

\author{
Summary \\ Reactivity of none lysosomal enzymes in blood plasma of sheep has been estimated. After $48 \mathrm{~h}$ protein \\ deprivation the activity of BGLU, BGAL, AAP and LAP increased significantly, NAGL and LL activity \\ decreased, EL and KF activity remained unchanged.
}

Key Words: sheep, lysosomal enzymes, protein starvation, blood serum

\section{Zusammenfassung}

Titel der Arbeit: Der Einfluss von Eiweißmangel auf die Aktivität von lysosomalen Enzymen im Blutspiegel beim Schaf

Die Aktivitäten der lysomalen Enzyme wurden in Blutplasma der Schafe nach 48 stündiger Eiweißhungerperiode bestimmt. Die Aktivitäten von BGLU, BGAL, AAP und LAP erhöhten sich, die von NAGL und LL verminderten sich signifikant. Keine Veränderungen zeigten die Aktivitäten von EL und KF.

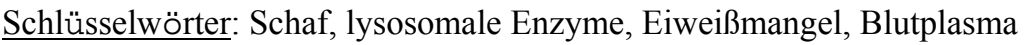

\section{Introduction}

The role of the cell lysosomal compartment in the processes of protein degradation is connected with the adaptation ability of an organism (BAIRATI et al., 1997; MIYAWAKI, 1988; PFEFFER, 1991; SEGLEN and BOHLEY, 1992; STORRIE, 1995; STORRIE and DESJARDINS, 1996). Lysosomal enzymes may constitute a good model for studies of these adaptation processes on the cell level (BRUNK et al., 1996; CALDER, 1989; DESJARDINS, 1995; HICKS, 1995; KOŁĄTAJ et al., 1996; LOMBARDO et al., 1996; WITEK et al., 1994; 1995; 1996).

Also the problem of stress in animal breeding is becoming an important research problem, connected with its negative effects on productivity (HERSHOCK and VOGEL, 1989; KOŁĄTAJ et al., 1998; 1996; 1995; ).

In the literature available no information was found on lysosomal enzyme activities in the tissues of sheep, which would present the animals in the physiological conditions and in response to stress. WITEK et al. (1996) observed the activity of lysosome enzymes in leucocytes and blood plasma of sheep as result of mercury poisoning only. The present studies are connected with the activity of model lysosomal enzymes in the blood plasma of sheep maintained in farm conditions, fed normally and next restrictived for a short period. Fasting or restriction of food is some specific type of stress (FIDANZA, 1980; KOŁĄTAJ, 1993). In domestic animals it still occurs quite often (KLUSEK et al., 1997). 
Material and Methods

The studies were performed on 21 Booroola rams 1-4 year old (Table 1) which came from the breeding farm belonging to the Polish Academy of Sciences, Institute of Genetics and Animal Breeding in Jastrzębiec. The animals received unlimited hay, silage and concentrate according to norm for farm. They had a constant access to water. All the animals were in good conditions of breeding, nursing and professional veterinary care.

Table 1

Least squares means (LSM) and ( \pm se) for activity of studied lysosomal enzymes in blood serum of sheep (nMol/mg protein/hour)

\begin{tabular}{|c|c|c|c|c|c|c|}
\hline \multicolumn{3}{|c|}{ Treatment } & \multicolumn{4}{|c|}{ Group of animals (years) ${ }^{*}$} \\
\hline & $\begin{array}{c}\text { before } \\
\text { starvation } \\
(1)\end{array}$ & $\begin{array}{c}\text { after } \\
\text { starvation } \\
(2)\end{array}$ & 1 & 2 & 3 & 4 \\
\hline $\mathrm{N}$ & 21 & 21 & 14 & 16 & 6 & 6 \\
\hline BGRD & $\begin{array}{l}0,208 \\
\pm 0,034\end{array}$ & $\begin{array}{l}0,280^{\mathrm{ns}} \\
\pm 0,034\end{array}$ & $\begin{array}{l}0,256 \\
\pm 0,037\end{array}$ & $\begin{array}{l}0,238 \\
\pm 0,035\end{array}$ & $\begin{array}{l}0,268 \\
\pm 0,057\end{array}$ & $\begin{array}{l}0,215^{\mathrm{ns}} \\
\pm 0,057\end{array}$ \\
\hline BGLU & $\begin{array}{l}0,160 \\
\pm 0,011\end{array}$ & $\begin{array}{l}0,216^{* * *} \\
\pm 0,011\end{array}$ & $\begin{array}{l}0,204 \\
\pm 0,012\end{array}$ & $\begin{array}{l}0,184 \\
\pm 0,012\end{array}$ & $\begin{array}{l}0,162 \\
\pm 0,019\end{array}$ & $\begin{array}{l}0,202^{\mathrm{ns}} \\
\pm 0,019\end{array}$ \\
\hline NAGL & $\begin{array}{l}4,377 \\
\pm 0,187\end{array}$ & $\begin{array}{l}2,409^{* * *} \\
\pm 0,187\end{array}$ & $\begin{array}{l}4,360^{\mathrm{AaB}} \\
\pm 0,207\end{array}$ & $\begin{array}{l}2,844^{\mathrm{A}} \\
\pm 1,194\end{array}$ & $\begin{array}{l}2,840^{\mathrm{B}} \\
\pm 0,316\end{array}$ & $\begin{array}{l}3,528^{a} \\
\pm 0,316\end{array}$ \\
\hline BGAL & $\begin{array}{l}0,506 \\
\pm 0,031\end{array}$ & $\begin{array}{l}0,597^{*} \\
\pm 0,031\end{array}$ & $\begin{array}{l}0,560 \\
\pm 0,034\end{array}$ & $\begin{array}{l}0,524 \\
\pm 0,032\end{array}$ & $\begin{array}{l}0,635 \\
\pm 0,052\end{array}$ & $\begin{array}{l}0,488^{\mathrm{ns}} \\
\pm 0,052\end{array}$ \\
\hline $\mathbf{L L}$ & $\begin{array}{l}0,797 \\
\pm 0,092\end{array}$ & $\begin{array}{l}0,462^{*} \\
\pm 0,092\end{array}$ & $\begin{array}{l}0,432^{\mathrm{A}} \\
\pm 0,101\end{array}$ & $\begin{array}{l}0,487^{\mathrm{B}} \\
\pm 0,095\end{array}$ & $\begin{array}{l}0,987^{\mathrm{AB}} \\
\pm 0,155\end{array}$ & $\begin{array}{l}0,613 \\
\pm 0,155\end{array}$ \\
\hline EL & $\begin{array}{l}2,707 \\
\pm 0,169\end{array}$ & $\begin{array}{l}2,483^{\mathrm{ns}} \\
\pm 0,169\end{array}$ & $\begin{array}{l}2,181 \\
\pm 0,187\end{array}$ & $\begin{array}{l}2,693 \\
\pm 0,175\end{array}$ & $\begin{array}{l}2,743 \\
\pm 0,285\end{array}$ & $\begin{array}{l}2,762^{\mathrm{ns}} \\
\pm 0,285\end{array}$ \\
\hline KF & $\begin{array}{l}2,242 \\
\pm 0,513\end{array}$ & $\begin{array}{l}2,233^{\mathrm{ns}} \\
\pm 0,513\end{array}$ & $\begin{array}{l}3,455 \\
\pm 0,568\end{array}$ & $\begin{array}{l}1,855 \\
\pm 0,531\end{array}$ & $\begin{array}{l}1,778 \\
\pm 0,867\end{array}$ & $\begin{array}{l}1,862^{\mathrm{ns}} \\
\pm 0,867\end{array}$ \\
\hline AAP & $\begin{array}{l}9,520 \\
\pm 0,420\end{array}$ & $\begin{array}{l}12,210^{\text {*** }} \\
\pm 0,420\end{array}$ & $\begin{array}{l}11,100 \\
\pm 0,470\end{array}$ & $\begin{array}{l}10,930 \\
\pm 0,440\end{array}$ & $\begin{array}{l}9,910 \\
\pm 0,710\end{array}$ & $\begin{array}{l}10,520^{\mathrm{ns}} \\
\pm 0,710\end{array}$ \\
\hline LAP & $\begin{array}{r}79,960 \\
\pm 3,060\end{array}$ & $\begin{array}{l}109,380^{* * *} \\
\pm 3,060\end{array}$ & $\begin{array}{l}89,800 \\
\pm 3,380\end{array}$ & $\begin{array}{l}93,970 \\
\pm 3,170\end{array}$ & $\begin{array}{l}94,270 \\
\pm 5,170\end{array}$ & $\begin{array}{l}100,630^{\mathrm{ns}} \\
\pm 5,170\end{array}$ \\
\hline
\end{tabular}

The animals maintained in these conditions were treated as blood donors of the control group. Next, the animals were deprived for 48 hours the silage and concentrate, therefore the protein components but they had a constant access to straw only. We did not apply the full starvation in order to not evoke the emotional stress connected with a total lack of food. The essence of our intention was a deprivation of food protein during this period. After 48 hours of that protein starvation the blood was drawn again. Both times, before $48 \mathrm{~h}$ period of food restriction (control) and after this time, $10 \mathrm{ml}$ of blood were drawn between $8^{30}-10^{30}$ a.m. to test tubes containing heparin and centrifuged for 15 minutes at $20.000 \mathrm{~g}$ in K-24 centrifuge. The blood samples were 
taken from the neck vein of all individuals. In the blood serum obtained the following lysosomal enzymes were determined: ß-glucoronidase (BGRD) - EC 3.2.1.31; $ß$ glucosidase (BGLU) - EC 3.2.1.21; N-acetyl -ß-glucosaminidase (NAGL) - EC 3.2.1.30; ß-galactosidase (BGAL) - EC 3.2.1.23; lysosome lipase (LL) - EC 3.1.1.2; alanine aminopeptidase (AAP) - EC 3.4.11.2; leucine aminopeptidase (LAP) - EC 3.4.11.1; acid phosphatase (KF) - EC 3.1.3.2; lysosome esterase (EL) - EC 3.1.1.2.

The activity of BGRD, BGLU, NAGL, BGAL and KF was determined according to the method of BARRETT (1972), LAP - by method of PFEIDERER and CELLIERS (1963), AAP by method of PFEIDERER et al. (1964), EL and LL - by MAIN'S method (1960). The enzymatic activity was expressed in $\mathrm{nMol} / \mathrm{mg}$ of protein/hour. Plasma protein was estimated according to the method of KIRSCHKE and WIEDERANDERS (1984).

The reagents used were produced by Sigma (Sigma - Aldrich Corp.) firm. The results obtained were analysed statistically using the two-way analysis of variance.

\section{Results}

The results obtained are presented in Tables 1 - 3 and Figure 1. After 48 hours of protein fasting increased significantly the activity of BGLU $(\mathrm{F}=12.385)$, BGAL $(\mathrm{F}=4.280)$, AAP $(\mathrm{F}=20.516), \mathrm{LAP}(\mathrm{F}=46.216)$. The activity of NAGL $(\mathrm{F}=55.356)$ and $\mathrm{LL}(\mathrm{F}=6.675)$ decreased significantly while $\mathrm{BGRD}$, EL and KF remained unchanged.

Table 2

The example of the interaction (in one case only) for least squares means (LSM) and ( \pm se) for activity of studied lysosomal enzyme $\mathrm{KF}^{\mathrm{x}}$

\begin{tabular}{|c|c|c|c|}
\hline \multirow[b]{2}{*}{ Factor } & \multirow[b]{2}{*}{$\mathrm{N}$} & \multicolumn{2}{|c|}{$\mathrm{KF}$} \\
\hline & & LSM & se \\
\hline \multicolumn{4}{|l|}{ Treatment $\mathrm{x}$ group } \\
\hline $1 \times 1$ years & 7 & $1.859^{\mathrm{a}}$ & 0.803 \\
\hline $1 \times 2$ years & 8 & 2.465 & 0.751 \\
\hline $1 \times 3$ years & 3 & 2.123 & 1.227 \\
\hline $1 \times 4$ years & 3 & 2.520 & 1.227 \\
\hline $2 \times 1$ years & 7 & $5.051^{\mathrm{a}}$ & 0.803 \\
\hline $2 \times 2$ years & 8 & 1.245 & 0.751 \\
\hline $2 \times 3$ years & 3 & 1.433 & 1.227 \\
\hline $2 \times 4$ years & 3 & 1.203 & 1.227 \\
\hline
\end{tabular}

Means bearing the different superscript differ significantly at: $a, a: P \leq 0.05$

${ }^{\mathrm{x}} \backslash$ significance of differences between means was estimated by Duncan's test;

The analysis of variance (Table 3) indicated, that as regards NAGL and LL the age of the animals played a significant role in determining the enzyme activity $(\mathrm{F}=10.984, \mathrm{P}$ $\leq 0.001$ and $\mathrm{F}=3.302, \mathrm{P} \leq 0.03$, respectively). The age $\mathrm{x}$ treatment interaction revealed the significant value $(\mathrm{F}=3.244, \mathrm{P}<0.034)$ only in relation to acid phoshatase $-\mathrm{KF}$ (Fig.).

\section{Discussion}

Stress has already been defined many times (FRIEND, 1980; MOBERG, 1985; SPENCER, 1995; YOUSEF, 1985). There are the suggestions that stress should be understood as the sudden informatic and energetic excitation of the cell or the organism as a whole (KOŁĄTAJ, 1993). It is known that numerous regulatory 
possibilities of homeostasis reveal under the pressure of environment (KLASSING, 1985). An analysis of our results obtained indicates that $48 \mathrm{~h}$ protein fasting is an important stress factor in relation to lysosomal enzymes and it can cause the changes of their activities. The activity of four enzymes investigated increased and the activity of two enzymes decreased.

Table 3

The analysis of variance for the lysosomal enzyme activities in blood serum of studied sheep

\begin{tabular}{|c|c|c|c|c|c|c|}
\hline Enzyme & Factor & DF & $\begin{array}{l}\text { Sum of } \\
\text { squares }\end{array}$ & $\begin{array}{c}\text { Mean } \\
\text { squares }\end{array}$ & $\mathrm{F}$ & $\begin{array}{c}\mathrm{P} \\
\text { (probability) }\end{array}$ \\
\hline \multirow{4}{*}{ BGRD } & Treatment $(\mathrm{T})$ & 1 & 0.4446 & 0.4446 & 2.291 & 0.1394 \\
\hline & Age (A) & 3 & 0.0110 & 0.0037 & 0.189 & 0.9034 \\
\hline & $\mathrm{T} \times \mathrm{A}$ & 3 & 0.0231 & 0.0077 & 0.396 & 0.7567 \\
\hline & Error & 34 & 0.6627 & 0.1950 & - & - \\
\hline \multirow{4}{*}{ BGLU } & Treatment $(\mathrm{T})$ & 1 & 0.0263 & 0.0263 & 12.385 & 0.0013 \\
\hline & Age (A) & 3 & 0.0087 & 0.0029 & 1.367 & 0.2694 \\
\hline & $\mathrm{T} \times \mathrm{A}$ & 3 & 0.0075 & 0.0025 & 1.181 & 0.3316 \\
\hline & Error & 34 & 0.0723 & 0.0021 & - & - \\
\hline \multirow{4}{*}{ NAGL } & Treatment $(\mathrm{T})$ & 1 & 33.1673 & 33.1673 & 55.356 & 0.0000 \\
\hline & Age (A) & 3 & 19.7430 & 6.5810 & 10.984 & 0.0000 \\
\hline & $\mathrm{T} \times \mathrm{A}$ & 3 & 2.7651 & 0.9217 & 1.538 & 0.2223 \\
\hline & Error & 34 & 20.3717 & 0.5992 & - & - \\
\hline \multirow{4}{*}{ BGAL } & Treatment (T) & 1 & 0.7026 & 0.7026 & 4.280 & 0.0462 \\
\hline & Age (A) & 3 & 0.7813 & 0.2604 & 1.586 & 0.2107 \\
\hline & $\mathrm{T} \times \mathrm{A}$ & 3 & 0.1142 & 0.3807 & 2.319 & 0.0929 \\
\hline & Error & 34 & 0.5581 & 0.1642 & - & - \\
\hline \multirow{4}{*}{ LL } & Treatment (T) & 1 & 0.9593 & 0.9593 & 6.675 & 0.0142 \\
\hline & Age $(\mathrm{A})$ & 3 & 1.4236 & 0.4745 & 3.302 & 0.0318 \\
\hline & $\mathrm{T} \times \mathrm{A}$ & 3 & 0.3046 & 0.1015 & 0.706 & 0.5548 \\
\hline & Error & 34 & 4.8860 & 0.1437 & - & - \\
\hline \multirow{4}{*}{ EL } & Treatment $(\mathrm{T})$ & 1 & 0.4289 & 0.4289 & 0.880 & 0.3549 \\
\hline & Age (A) & 3 & 2.7252 & 0.9084 & 1.863 & 0.1545 \\
\hline & $\mathrm{T} \times \mathrm{A}$ & 3 & 1.1563 & 0.3854 & 0.790 & 0.5077 \\
\hline & Error & 34 & 16.5796 & 0.4876 & - & - \\
\hline \multirow{4}{*}{ KF } & Treatment $(\mathrm{T})$ & 1 & 0.0006 & 0.0006 & 0.000 & 0.9908 \\
\hline & Age (A) & 3 & 24.3727 & 8.1242 & 1.800 & 0.1658 \\
\hline & $\mathrm{T} \times \mathrm{A}$ & 3 & 43.9206 & 14.6402 & 3.244 & 0.0339 \\
\hline & Error & 34 & 153.4656 & 4.5137 & - & - \\
\hline \multirow{4}{*}{ AAP } & Treatment $(\mathrm{T})$ & 1 & 62.4357 & 62.4357 & 20.516 & 0.0001 \\
\hline & Age (A) & 3 & 8.7480 & 2.9160 & 0.958 & 0.4236 \\
\hline & $\mathrm{T} \times \mathrm{A}$ & 3 & 10.4747 & 3.4916 & 1.147 & 0.3441 \\
\hline & Error & 34 & 103.4729 & 3.0433 & - & - \\
\hline \multirow{4}{*}{ LAP } & Treatment $(\mathrm{T})$ & 1 & 7407.3790 & 7407.3790 & 46.216 & 0.0000 \\
\hline & Age (A) & 3 & 503.7801 & 167.9267 & 1.048 & 0.3840 \\
\hline & $\mathrm{T} \times \mathrm{A}$ & 3 & 738.2594 & 246.0865 & 1.535 & 0.2231 \\
\hline & Error & 34 & 5449.3956 & 160.2763 & - & - \\
\hline
\end{tabular}

$* * \mathrm{P}<0.01, * * * \mathrm{P}<0.001$

The decrease of NAGL and LL activity in the blood plasma during fasting was observed earlier on rabbits by WITEK et al. (1995). Their activity may be connected with the changed rate of synthesis or the degradation of fats and carbohydrates in the cell. 


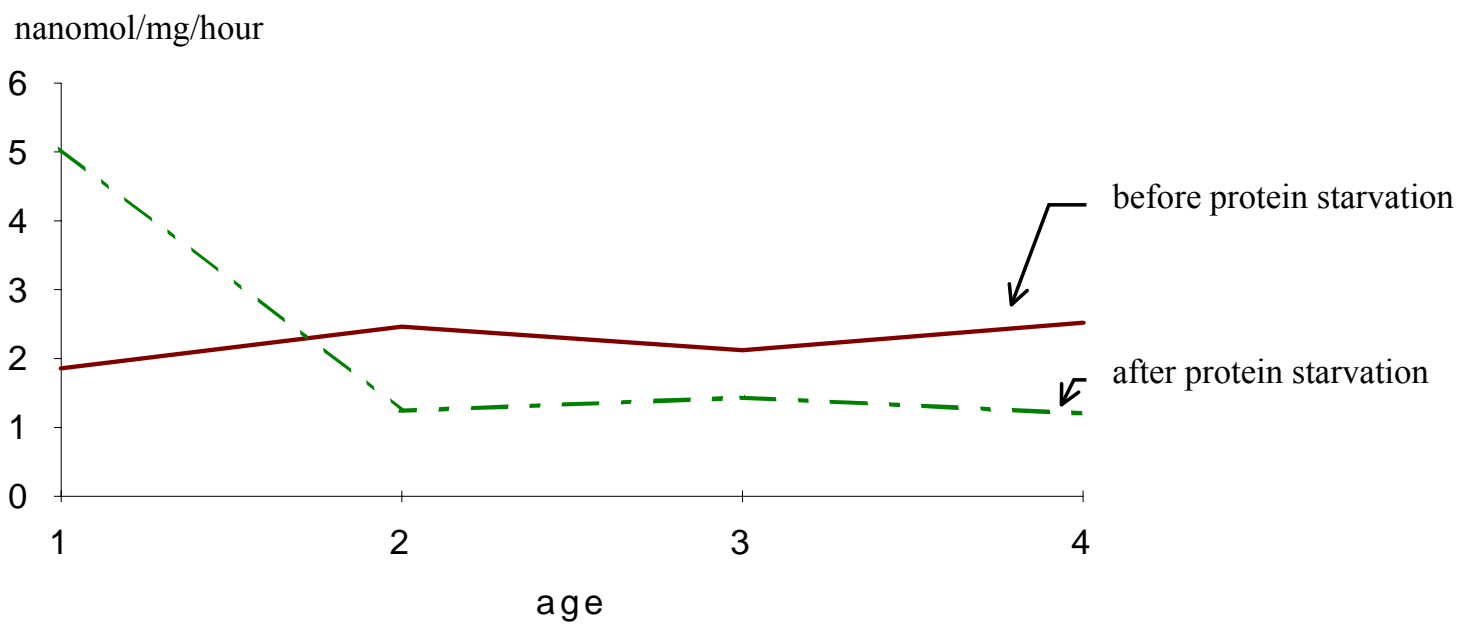

Figure: The example of interaction treatment $\mathrm{x}$ age for acid phosphatase (KF) activity

The activity of BGLU, BGAL, AAP and LAP enzymes increased. It may be connected probably with the degradation intensity of protein and protein - carbohydrate compounds in the cell. Such selective changes may suggest the different of breaking stages of the lysosome arrangement membranes. This phenomenon may be treated as an example of the adaptation of the cell lysosome arrangement to conditions of $48 \mathrm{~h}$ lasted protein fasting. In this period the glycoprotein and lipoprotein metabolism rate increases, as well as the rate of passage of aminoacids from the degraded proteins to mitochondria in order to maintain a correct level of oxidative phosphorylation.It is known that different types of proteins have a different period of half-life. It proves to their differently controlled degradation because metabolism must take place also during protein fasting.

The problems of human and animal adaptation to the starvation and to the restricted feeding remain in the centre of interest of many researches (CHEREL et al., 1992; FIDANZA, 1980; KOŁĄTAJ, 1993; WITEK et al., 1995).

\section{References}

BAIRATI, CH.; GOI, G.;BOLLINI, D.; ROGGI, C.;LUCA, M.; APOSTOLI, P.;LOMBARDO, A.: Effects of lead and manganese on the release of lysosomal enzymes in vitro and in vivo.Clinica Chimica Acta 261 (1997), 91 - 101

BARRET, A.J.:

Lysosomal enzymes. In „Lysosomes. A Laboratory Handbook” (Edited by DINGLE, J.T.), North Holand Publishing Co., Amsterdam (1972), 46 - 135

BRUNK, U.T.; ZHANK H.; ROBERG K.; OLLINGER K.:

Lethal hydrogen peroxide toxicity involves lysosomal iron - catalyzed reactions with membrane damage. Redox Report 1 (1996), 267 - 277

CALDER, P.C.:

Regulation of lysosomal glycogen metabolism: studies of the actions of mammalian acid alfa glucosidases. Int. J. Biochem. 21 (1989), 569 - 576

CHEREL, Y.; ROBIN, J.P.; HEITZ, A; CALGARI, CH.; LE MACHO, Y.:

Relationships between lipid avaibility and protein utilization during prolonged fasting J. Comp. Physiol. B. 162 (1992), $305-313$

DESJARDINS, M.:

Biogenesis of phagolysosomes: the „kiss and run” hypothesis. Trends Cell Biol. 5 (1995), 183 - 186

FIDANZA, F.:

Effects of Starvation on Body Composition. Am. J. Clin. Nutr. 33 ( 1980), 1562 - 1566

FRIEND, T.H:

Stress : What It is and How Can It Be Quantiefied. Int. J. Stud. Anim. Prod. 6 (1980), 366 - 374 
HERSHOCK, D.; VOGEL, W.H.:

The effects of immobilization stress on serum triglycerides, nonestrified fatty acids and total cholesterol in male rats after dietary modifications. Life Sci. 45 (1989), 157 - 165

HICKS ,J.J.:

Lysosomal system in hormonal mechanism. Ginecol. obstet. Mex. 63 (1995), 68 - 73

KIRSCHKE, H.; WIEDERANDERS, B.:

Methoden zur Aktivitätbestimmung von Proteinasen. Martin Luther Univ., Halle - Wittenberg Beiträge, Halle - Salle, (1984), 11 - 17

KLASSING, K.C.:

Influence of stress on protein metabolism. In „Animal Stress”( Edited by MOBERG, G.P), Am. Physiol. Soc., Bethesda, Maryland (1985), 269 - 281

KLUSEK, J.; KOŁĄTAJ, A.; ŚWIDERSKA - KOŁACZ, G.:

The influence of starvation on the level of some lipids in pigs. Arch. Tierz., Dummerstorf 40 (1997), 365-369

KOŁĄTAJ, A.:

Phenomenon of stress. Kieleckie Towarzystwo Naukowe, Kielce (Poland), (1993), 5 -185

KOŁĄTAJ, A.; RYSIÑSKA, J.; FLAK, P.:

Influence of selection on reaction to stress in mice. III. Influence of fasting, immobilization and exposure to cold on lactate dehydrogenase and aldolase activity in liver and kidney. J.Anim. Breed. Genet. 112 (1995), 224 - 223

KOŁĄTAJ, A.; STÊPKOWSKA, A.; FLAK, P.:

Influence of selection on reaction to stress in mice. IV Influence of fastng, immobilization and exposure to cold on aminotransferases AspAT and AlAT in liver and kidney. J. Anim. Breed. Genet. 113 (1996), $119-124$

KOŁĄTAJ A.; SOMMER, A.; WITEK, B.; NITRAY, J.; FLAK, P.:

The effect of exogenous glucose on the activity of lysosomal enzymes, the glucose and insulin concentration in the blood plasma of young bulls. Arch. Tierz., Dummerstorf 41 (1998) 4, 371 - 377

LOMBARDO, A.; BAIRATI, C.; GOI, G.; ROGGI, C.; MACCARIANI, L., BOLLINI, D.; BURLINA, A.:

MAIN, A.R.: Plasma lysosomal glycohydrolases in a general population. Clin. Chim. Acta 247 (1996), 3949 - 3958

The purification of the enzyme hydrolysing diethyl-p- nitrophenyl phosphate (paraoxon ) in sheep serum. J. Biol. Chem. 74 (1960), 11 -20

MIYAWAKI, T.:

The lysosomal stabilizing effect of some antishock agents. Eng. Abstr. $37: 815$ (1988), 815 - 822

MOBERG, G.P.;

Animal stress. (Edited by MOBERG, G.P. ), Am. Physiol. Soc.,Bethesda, Maryland, USA, (1985), 1 385

PFEFFER, S.R.:

Targeting of proteins to the lysosome. Curr. Top Microbiol. Immunol. 170 (1991), 43 - 63

PFEIDERER, G.; CELLIERS, P.G.: Isolierung einer Aminopeptydase aus Nierenpartikeln. Biochem. Zeitschr. 340 (1963), 552-564

PFEIDERER, G.; CELLIERS, P.G.; STANULOVIC, M.; WASCHMUTH, E.D.; BRAUNITER,G. :

Eigenschaften und analytische Anwendungen von Aminopeptydase aus Nierenpartikeln. Biochem. Zeitschr. 340 (1964), 552 - 564

SEGLEN, P.O.; BOHLEY, P.:

Autophagy and other vacuolar degradation mechanisms. Experentia 48 (1992), 158 - 168

SPENCER, G.S.G.:

Quantitative indicators of stress in stress - susceptibility and stress - resistant breeds of pigs. Proc. N.

STORRIE, B.: Zeal. Soc. Anim. Prod. 5 (1995), 187 - 189

The Lysosome: its role in the biology of the cell and organism. In „Principles of Medical Biology”. (Edited by BITTAR, E.E. and BITTAR, N.). JAI Press Inc., Greenwich CT, 3 (1995), 1 - 18

STORRIE, B.; DESJARDINS, M.:

The biogenesis of lysosomes; it ,a kiss and run” continuous fusion and fission process? BioEssays, 18 (1996), 895 - 903

WITEK, B.; KOŁĄTAJ, A.; RAFAY, J.:

The activity of lysosome enzymes in rabbits during the process of adaptation to stress. Arch. Tierz., Dummerstorf 37 (1994), 55-566

WITEK, B.; KOŁĄTAJ, A.; KRÓL ,T.:

Adaptative changes in the glucose level and activity of some lysosomal enzymes in the plasma of starved rabbits. Arch. Tierz., Dummerstorf 38 (1995), 341 - 345 
WITEK, B.; LEGATH. J.; KOŁĄTAJ, A.; KALINSKA ,O.; BANASIK, A.; BIEÑKA-MICHALIK, A.:

The effect of small doses of mercury on the level of selected lysosomal enzymes in the plasma and lymphocytes of sheep. Gen Pharm. 27 (1996) 5, 901 - 903

YOUSEF, M. K.:

Stress Physiology in Livestock, Ungulates. CRC Press INC., Bocca Raton, Florida, USA (1985), 5 - 495

Received: 2000-10-26

Accepted: 2001-12-06

Corresponding author

Prof. Dr. ADAM KOŁĄTAJ

Polish Academy of Sciences

Institute of Genetics and Animal Breeding,

Jastrzębiec, 05-551 Mroków, Poland 